\title{
Density and dispersion: the co-development of land use and rail in London
}

\author{
David Levinson****
}

\begin{abstract}
This article examines the changes that occurred in the rail network and density of population in London during the 19th and 20th centuries. It aims to disentangle the 'chicken and egg' problem of which came first, network or land development, through a set of statistical analyses clearly distinguishing events by order. Using panel data representing the 33 boroughs of London over each decade from 1871 to 2001, the research finds that there is a positive feedback effect between population density and network density. Additional rail stations (either Underground or surface) are positive factors leading to subsequent increases in population in the suburbs of London, while additional population density is a factor in subsequently deploying more rail. These effects differ in central London, where the additional accessibility produced by rail led to commercial development and concomitant depopulation. There are also differences in the effects associated with surface rail stations and Underground stations, as the Underground was able to get into central London in a way that surface rail could not. However, the two networks were weak (and statistically insignificant) substitutes for each other in the suburbs, while the density of surface rail stations was a complement to the Underground in the center, though not vice versa.
\end{abstract}

Keywords: transport, land use, London Underground, London railways, network growth, induced demand, induced supply, panel data, cross-section time series

JEL classifications: R42, R31, R21, N73, N74

Date submitted: 23 May 2007 Date accepted: 25 September 2007

\section{Introduction}

Does development lead to the construction of new infrastructure to support it, or do extensions of the transport network enable and induce new development?

It has been observed that infrastructure (supply) investments increase traffic (demand). The relationship between infrastructure and traffic has largely been seen as one-way, with infrastructure as the explanatory variable and traffic as the dependent variable. The causes of increases in traffic are several, more trip-makers due to more development in the long run, and more trips per trip-maker, changes in destination in the medium term, and shifts in route, mode or departure time in the short-run. Downs (2004) has referred to these short-run changes as the 'Iron Law of Congestion' or 'Triple Convergence'.

\footnotetext{
*Department of Civil Engineering, University of Minnesota, Minneapolis, MN 55455, USA. email<dlevinson@umn.edu>

$* *$ Department of Civil and Environmental Engineering, Imperial College, London, UK.
} 
This is of course not a new observation. Empirical examples include the opening of the Great West Road that 'carried four and a half times more vehicles than the old route was carrying; no diminution, however, occurred in the flow of traffic on the old route...' (Bressey and Lutyens, 1938) cited in (Goodwin, 1996) and the Pennsylvania Turnpike that was projected to carry only 715 vehicles per day, but actually carried tens of thousands (Rae, 1971; Gifford, 1983).

In transportation research, what has been dubbed the 'induced demand' problem has developed around it a literature that aims to measure (typically at the county or state level) how much additional traffic [usually measured as vehicle miles (kilometers) of travel] will result from additions to road capacity [usually measured as lane miles (kilometers) of capacity] (Hansen and Huang, 1997; Noland and Lem, 2002; Cervero, 2002, 2003; Goodwin and Noland, 2003; Behrens and Kane, 2004). Other studies have examined the effect of bypasses and modeling forecasts (SACTRA, 1994). To an economist, this is simply a question of supply and demand, and it is no surprise that additional supply will lead to lowered costs and thus additional consumption, however, in engineering practice, analysis traditionally assumed demand was perfectly inelastic, and only recently has the elasticity of demand entered as a factor to be considered. Models to estimate property values (and thus implicitly demand) as a function of transport availability have seen widespread use, e.g. Gibbons and Machin (2004) examined prices in London as they relate to nearby rail presence, and McDonald and Osuji (1995) conducted a similar study in Chicago.

To a large extent, while dealing with spatial variables, the research typically remains aggregate and macroscopic. In part, that is due to the lack of tools available to analyze network elements in a statistically rigorous way, in part due to data availability. Exceptions to the use of macroscopic analyses include Parthasarathi et al. (2003) that used link-level network expansion data to examine changes in link-level utilization, Goodwin et al. (1998) that showed that the bridge closures reduced traffic levels, Levinson and Kanchi (2002) that used person-level data to examine changes in individual travel budgets as a result of aggregate changes in capacity and Mokhtarian et al. (2002) that examined changes in flows on matched pairs of links.

The literature, which examines traffic, has important policy implications, but of itself, cannot fully distinguish the causes of the increase of traffic. For instance, examining the immediate effects of a road opening on traffic versus the changes which take place many years later may help in part to distinguish how much is due to short-run changes (route, mode and departure time), it cannot discern between those changes or clearly differentiate between short and medium and early long-run changes.

Only a fraction of the literature has attempted to examine empirically how demand affects supply (Levinson and Karamalaputi, 2003). However, a few papers are notable in attempting to examine the question as a two-way process. Studies using 2SLS instrumented-variables regression, (Fulton et al., 2000) and simultaneous equation systems (Cervero and Hansen, 2002) to estimate both vehicle travel and lane capacity suggest that similar forces are at work affecting changes in both travel demand and infrastructure supply, and both studies found that increases in supply Granger-cause increases in demand, while Cervero and Hansen (2002) found that demand also Granger-causes increase in supply. A Markov chain model where the state that was being predicted was a combination of land use type and infrastructure type found relationships between the two, with development of land driving development of infrastructure and vice versa (Levinson and Chen, 2005). 
The relationships of infrastructure to development has been treated qualitatively in a number of examples. The development of streetcar suburbs in Boston, as the name suggests, show the correlation between development and suburbanization (Warner, 2004), while similar processes took place in Minneapolis and St Paul (Lowry, 1979). In London, there have been several descriptive studies of the effects of the Underground on suburban development, discussed in the next section. Clark (1957) describes the relationship between transport and land use and Mogridge (1997) looks especially at the case of London.

There is a much broader literature concerning changes to rural areas. In part this is due to opportunity, there are more rural than urban areas; and in part this is due to ease of analysis, there are fewer conflating factors in slower changing rural areas than in cities. The topic has policy significance, with roads often being promoted as tools for economic development (Humphrey and Sell, 1975; Chi et al., 2006). The change in population of minor civil divisions tends to increase due to new nearby highway capacity (Voss and Chi, 2006), and counties with interstate highways received more migration than those without (Lichter and Fuguitt, 1980), though those near cities did much better economically than rural counties with interstate highways or those with no highways (Rephann and Isserman, 1994). Job growth tended to be contemporaneous with interstate construction (Miller, 1979). Only a few cases examine population changes in urban areas (Hobbs and Campbell, 1967; McLean and Adkins, 1971) due to highway construction.

Similar questions have been raised in the transportation and productivity literature that examines how much additional productivity, e.g. change in GDP, comes from additional investment in infrastructure. Again, in most of the literature, county- or state-level data is used, so the analysis is aggregate (Gramlich, 1994; Boarnet, 1998; Graham, 2005).

This article considers the relationship between infrastructure and development, and focuses on the question of whether rail is a centralizing or decentralizing force. The answer has salience for those who wish to understand, regulate or manage the development of cities. It is widely believed that high population density is an important factor in the success of rail systems, in large part because that density represents potential ridership within walking distance of the station (Bellomo et al., 1970; Richardson, 1973; Goodwin, 1975; Pushkarev and Zupan, 1977; Newman and Kenworthy, 1992; Frank and Pivo, 1994; Steiner, 1994; Cervero and Kockelman, 1997). However, just because rail depends on high density for success does not inherently mean that either (i) high density areas generate rail investment or (ii) rail creates high-density areas around stations.

In this article, it is tested whether both processes hold, that high density land development encourages the investment in rail infrastructure and that rail infrastructure increases densities. However, the story is more complicated because rail, as a transportation network, enables people to move from here to there. As such, it increases densities for certain activities (e.g. jobs) in some places (e.g. downtown), and for other activities (e.g. houses) in different places (e.g. the suburbs). By increasing densities for jobs in downtown, it is simultaneously decreasing housing densities in those same places both by making housing in the core more expensive (it is competing with commercial activities for scarce land) and making housing outside the core have greater accessibility. It is this shift of densities that requires a close examination. 
This joint process of infrastructure and land development location is called co-development, which encompasses the notions of both co-deployment and co-evolution. Both terms are appropriate, though they have somewhat different meanings. Evolution refers to the change in the state of a technology, here through research and development coupled with market or governmental selection. So, for instance, as transport changes from horse drawn omnibuses to electric trams, we say that evolution has taken place. As houses get larger and provide more space per resident, a similar evolution has taken place.

Deployment refers to the spatial extent over which a particular technology is extant. While the new technology of the London Underground was discussed for many years and first opened (with steam power) in 1863 between Farringdon and Paddington stations on the Metropolitan Line, it was many years before it was fully deployed to the extent seen today.

The idea of co-evolution has received currency in a number of fields. In biology, it refers to the change in the genetic makeup of one species as another species also changes. Examples include the relationship between certain insects and the flowering plants they pollinate. Durham (1991) applies the idea to human culture that responds to the environment, and by doing so, changes the environment over which it operates. Deacon (1997) makes similar arguments about the relationship with human language and the brain.

Co-deployment is a related concept, but refers to the location of the technology (or species) in space. As one technology is deployed, related technologies respond to the change in their environment that the first technology created. While no new technologies are necessarily created, technologies that were successful in one area can now follow related complementary technologies to new territory.

The implications of this are several. As cities grow and reach new stages in one technology [say a new building technology (like elevators) that enables changes in land use] that innovation makes possible and demands new stages in its complements (e.g. transportation of larger numbers of people to take advantage of the denser arrangement of jobs). Once those technologies are available and feasible, they too can be deployed. As cities get larger (and as technologies advance), they acquire new transportation networks (walking, omnibus, railway, streetcar, cut-and-cover subway, paved road, deep level (tube) subway, divided highway, grade separated superhighway) relying on different motive power (human, animal, steam, electricity, diesel, gasoline). Some cities have now reached a stage of development, connecting the core with airports via high speed transport (e.g. the Shanghai Maglev), while others are considering a new level of rail transport (e.g. London's proposed Crossrail, or the Eurostar allowing commutes from Calais to London).

The article proceeds as follows. Background on the London case is provided. The next section discusses the network, population and employment data used in this study. The following sections describes the methods used in manipulating the data and the proposed hypotheses. The results are presented. Conclusions are drawn about the co-development of transportation and land use in London.

\section{Background on London}

What actually happened in London? As London is the case study under consideration here, understanding the facts on the ground is essential to properly formulating and 
estimating models describing it. In 1836, when London had just over 1 million residents, the first surface railway, the London and Greenwich, entered London. Most railways to serve the London region initially were built from the outside in, i.e. they provided intercity transport that connected London to other cities on the island of Great Britain. As such, they largely crossed rural areas between their origin and destination. When they arrived in greater London, they were required to terminate outside the heart of the region, the City of London.

A Royal Commission on Railway Termini, appointed in 1846, cordoned central London and prohibited railway terminals from locating within the cordon. ${ }^{1}$ By the 1850 s, there were a considerable number of terminals around London, and through travelers were required to find some means of surface transportation to connect through the city. This inspired the formation of a company to build what became known as the Metropolitan railway, to be the world's first Underground railway. Chartered in 1854 by Parliament, the Metropolitan connected surface rail stations at Paddington, Euston, St Pancras, King's Cross, and Farringdon when it opened in 1863.

Demand on the Metropolitan railway far exceeded the transfers of intercity passengers. A new market, which surely some had suspected was there, was revealed, and the Metropolitan was quickly emulated by other urban rail lines, mostly Underground. Between 1860 and 1869, 219 railway bills were placed before Parliament, though only a relative handful were approved (Simmons, 1978).

The Metropolitan was followed by the Metropolitan District Railway (the District Line), which ran to the south, and the two lines were eventually joined at both ends to form a Circle Line in 1884.

Other spur lines were also built in the 1860s, including the Hammersmith and City Railway, which was partially controlled by the Metropolitan (with the Great Western Railway), and whose planning started before the Metropolitan was complete. The Hammersmith and City was clearly aimed at connecting what was then a newly growing suburb (the area to the west of the West End, including Hammersmith and Ladbroke Grove) with the City, and was an early version of a line promoting speculative development. In fact, a scandal over development arose, illustrating some of the general characteristics of development at the time. The company had a contract with a construction firm to acquire the land needed for the line and to build the line. Unbeknownst to either the contractor or other shareholders of the company, two of the company directors (including John Parson, also deputy Chairman of the Metropolitan Railway and director of the Great Western, and Charles Blake, another director and one of the promoters of the line) bought undeveloped land at Portobello estate in the path of the proposed line and charged a markup to the contractor (Rummins), who was obligated to pay under terms of the contract. While the contractor was able to get this part of the contract cancelled, and a share-holder rebellion led by Cornelius Surgey (who was then sued for defamation by Parson) ousted the two directors, in the end the Railway still had to purchase the land for more than twice the price per acre (£2105) as the directors had recently acquired it for (£828) (The Portobello and St. Quintin estates, 1973). The former directors retained their shares in the railway, as well as the land from this and other estates in the area that were not required for track and acted as lenders

1 Between 1858 and 1860 some penetrations of the box were permitted by Parliament (at Victoria, Charing Cross and the extension from Blackfriars to Farringdon. 
to homebuilders. Blake and Parson thus were able to profit from both the transportation and land use changes in the area. While not all rail-induced development was this corrupt, principal-agent problems were pervasive.

The first Underground lines, the District and Metropolitan, were built using cut and cover techniques, which while disruptive to the road above and to public utilities, was a technology within grasp. Later deep tunneling techniques were perfected, and the first line using that technology, the City and South London Railway (now part of the Northern Line) was inaugurated in 1890. The advantages of these tube lines, which ran below the other lines inside the Circle, were less disruption. The costs of disruption grew with the city; cut and cover, in addition to creating conflicts with existing lines, became costlier over time.

The Underground lines quickly branched out, developing suburban services to feed their urban network. In this, they began to compete with the surface rail lines, more so north of the Thames, while in general building less south of the Thames. There are a number of hypotheses for why the north might differ from the south, ${ }^{2}$ this research can only test whether in fact it did.

While building suburban rail lines, they also helped build the suburbs. This was direct in the case of the Metropolitan Railway, which had the legal authority to develop land; but was indirect in the case of the other railways, which did not have such authority, though they could coordinate with developers in a mutually beneficial deal. Developments provided built-in customers, railways served as a marketing advantage for developers. Nevertheless, these lines were much more speculative, as at the time of construction the demand had yet to materialize. The role of the Metropolitan Railway in development has probably been over-emphasized. The developments created directly by the Metropolitan Railway and its subsidiaries amounts to about 15,000 houses on about 2200 acres (Foxell, 2005), which while significant, is about one half of one percent of all housing units in London. However, all of the developments which took advantage of the presence of suburban railways are much larger.

The surface railways did compete for new suburban traffic, though the network in the northwest quadrant of London had the lowest density of surface railway lines, and attracted the most Underground network.

2 Several reasons have been presented as to why the south of the Thames region differs from the north in terms of network development. First there is geology, conditions north of the Thames are more conducive to Underground construction. Second there is entrepreneurship, the railways south of the Thames may have been more entrepreneurial for a variety of historical and possibly random reasons, though an important non-random one was the degree of competition in the railways serving the south, the London, Chatham and Dover Railway was fiercely competitive with the South Eastern Railway, as was the London, Brighton and South Coast Railway, competition which did not end until consolidation in 1923. Third is geographical position, average trip lengths south of London were necessarily shorter than trip lengths north of London due to London's position in the south of England. The average journey length of travelers entering Euston station to the north was 64 miles $(103 \mathrm{~km})$ in 1846 (Simmons, 1978). It is only 59 miles $(95 \mathrm{~km})$ between London and Brighton on the coast. Fourth the consolidated Southern Railway entered into an agreement with the Underground group after 1923 that no future application in parliament for an extension of a UERL (Underground Electric Railways Company of London Limited) railway within the SRs area and within two miles $(3.2 \mathrm{~km})$ of an existing SR (Southern Railway) line should be made without giving 12 months notices to the SR (Croome and Jackson 1993). Fifth, the SR electrified quickly, before the other railways, and thus may have forestalled Underground competition. Since areas with better service from surface railways would have less demand for Underground service, the Underground largely avoided the competition. 


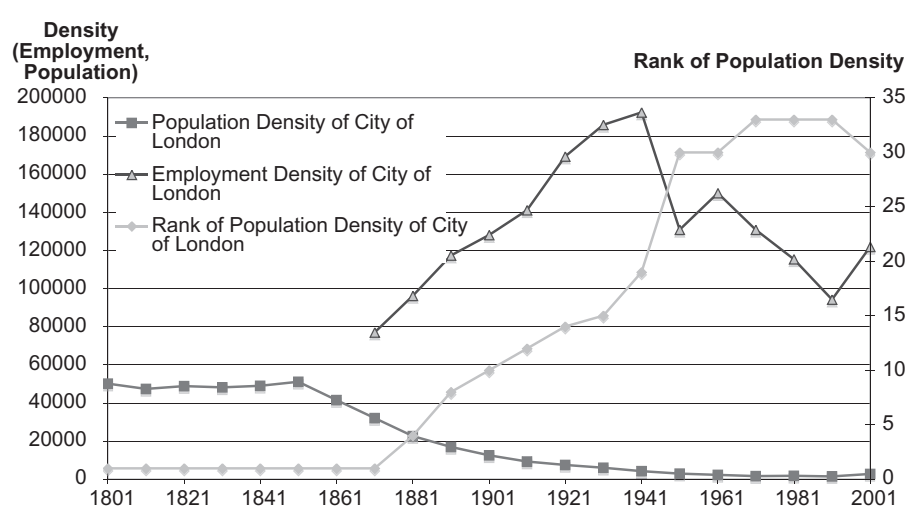

Figure 1. Population and employment density in the city of London. As employment rises, population drops, indicating competition for scarce space in the heart of Greater London.

The co-development of suburbs and Underground lines largely ended with the 1948 designation of a Green Belt around London, which not only resulted in the cancellation of proposed line extensions, it hemmed in the Underground-served suburbs. Later suburban developments jumped the Green Belt, but these were to be served by automobile, bus, or surface rail.

The trends in the core area of the City of London were quite different from the rest of London. As shown in Figure 1, the City has seen a long trend of depopulation from 1851 (prior to the first Underground line) and for many years saw increasing employment, lending support to the notion that the railways, especially the Underground enabled decentralization of residences and concentration of employment.

\section{Theory and hypotheses}

\subsection{Theory}

The relationship between transportation and land use has been much discussed. The theory being tested in this article is that of co-development, and the idea that just as transport drives land use, land use drives transport infrastructure. However, this chicken and egg problem must begin somewhere. When we have an existing place there is some existing transport network. The converse does not hold, there may be transport network serving 'placeless' areas, which are not developed, as the network may be serving places at its ends, but traversing undeveloped land to connect them. So transport can lead or follow land use, but land use must follow some (however primitive) transport network. Those networks may be 'nature's networks' as described in Levinson (2005), such as deer paths, rivers, harbors or places where rivers might be forded or bridged. And even an 'unnetworked plane' allows slow travel between all points, and can be thought of as a completely connected but low speed network (Xie and Levinson, 2007). This is summarized as the chain of development, described in Table 1.

Rail service, by increasing the distance that can be traveled in a given time over previous transport modes enabled commutes to be lengthier, and thus made more space available for residences at a given commute time. This spreading had the effect of lowering the population density in the core, particularly families of workers who lived in (or near) the core and previously traveled to work by slower modes (walking, omnibus). 
Table 1. The chain of development: transport leads to development leads to more transport leads to more development

Developed area

Undeveloped area
Development densifies in urban area after construction of new transport infrastructure

Constructing new (higher speed) mode in greenfields, to promote development
Constructing new (higher speed) mode in existing urbanized area (e.g. London transport in early years)

Still waiting

Rail would concomitantly increase the population density in the periphery (e.g. the end of the line), as it enables suburban workers to commute to the city. However, the same population in the core city was necessarily living at a higher density than that population in a ring surrounding the core because of the additional area in that ring. Thus, the density drops more in the core than it increases in the periphery for a given population.

It is posited that residents (workers) decentralize while trading-off desire to be near (in time) to workplaces against having as much space for as little money as possible ${ }^{3}$ ceteris paribus. We can think of these as off-setting centripetal and centrifugal forces. Firms on the other hand want to be near both their workforce and other firms (centripetal forces) and have low land costs (centrifugal forces), the strength of this desire of course depends on the sector, and how valuable economies of agglomeration are. The desire by residents for additional space (or spatial separation between themselves and their nearest neighbor) would not be matched by firms, who still had a desire to locate near other firms to conduct business quickly during the day and therefore would stay relatively centralized, or even increase their concentration. The reduced competition for land in the center (due to the out-migration of residents) further established the dominance of commercial activity in the core, particularly the City of London.

Rail services, while leading the market in undeveloped areas, would not see the advantage of leading the market too much. A rail company might expand to new markets outside the core, by building new lines or building stations and sidings on existing lines, but not to markets beyond those until the first had been at least partially developed. There are some economies of scale of expansion, so the extension would not be one station at a time, but rather a bundle of stations. Still, there are also costs to capital, and investing capital without a short-term payoff (by building far in advance of the market) reduces profitability. As a consequence, population moves out from the core of London in a relatively contiguous manner, development will only arrive in one borough after it has begun in closer-in boroughs. Moreover, it is moving out from the core. This leads to what can be dubbed 'neighbor effects', the state of a neighbor will positively affect a borough, so that an area with a neighbor that recently saw an increase in population is likely to see an increase as well.

One may posit, as a result of this process, a positive feedback relationship between transportation networks and development: the more network, the greater the development level; and the greater the development level, the more network. The type of development (commercial, residential) varies based on the preferences for 
agglomeration. So in the core: existing development leads to rail investment which leads to (largely) commercial development which leads to more rail; while in the periphery rail infrastructure attracts residential development which leads to more rail investment which leads to more (largely) residential development. Network effects suggest more stations (and links) have increasing value as they enable travelers to get to more places, particularly so as the network is first growing. So a network which sees a large percentage increase in growth is likely to drive development more than a network whose growth is slowing down. This is consistent with the notion of logistic or $S$-curves that are found thoughout transportation (Garrison and Levinson, 2006).

Thus, these cycles are not out of control, rather they seem to be limited. Limiting factors include exhaustion of economies of agglomeration in the center, decreasing returns to additional infrastructure investment. ${ }^{4}$ Each additional stop also delays the passengers already on board. Furthermore, ultimately, there is a minimum station spacing before the train does not actually leave one station before it gets to the next. As the total number of stations increases, we would expect the effect of each additional station to be less important.

The built environment changes slowly, most of the buildings here now will still be here in 10 years (and longer), serving largely the same functions, and housing about as many people (though densification can occur within the same structures as family sizes change, rooms are rented and roommates taken on). The population in one-time period is a significant explanatory factor for population in subsequent periods, as housing units reflect value that is unlikely to be wasted by going unused.

The change in population density in an area depends upon larger trends such as the overall population. A city that is growing will see more areas increasing density, a city that is shrinking will see more areas losing density.

The competition between Underground and surface rail is important. As noted in Section 2, the Underground had its start in the core of London where surface rail was prohibited, so the two were initially complements, and expanded into the suburbs, while surface rail came from the outside of London to the edge of the City. Suburban areas with more surface rail would discourage investment in the Underground, and areas with a high density of new Underground stations would discourage investment in surface rail.

The tests of the hypotheses control for spatial differences as a result of the River Thames and distance to the center (the City of London). The hypotheses are summarized as shown subsequently.

\subsection{Hypotheses}

(i) Population density

(a) Population density in the periphery is positively associated with the lagged increase in density of new (1) surface and (2) Underground rail stations.

(b) Population density in the periphery is positively associated with the lagged population density of the nearest borough between it and London (neighbor effect).

4 On a linear network with uniform density, one station every kilometer requires on average a one-half kilometer access plus egress cost, one station every half kilometer requires a quarter kilometer access plus egress cost, and so on. While a doubling of stations halves the access distance, the amount of distance reduced is diminishing. 
(c) Population density in the periphery is positively associated with the lagged network density of the nearest borough between it and London (neighbor effect).

(d) Population density in the core is negatively associated with the lagged increase in density of new (1) surface and (2) Underground rail stations (commercial uses substitute for residential).

(ii) Network density

(a) Network density in the periphery is positively associated with the lagged increase in population density.

(b) Network density in the periphery is positively associated with the population density of the nearest borough between it and London (neighbor effect).

(c) Network density in the periphery is positively associated with the network density of the nearest borough between it and London (neighbor effect).

(d) Underground and surface rail act as substitutes in the periphery, areas with more of one would get less of the other.

(e) Network density in the core is negatively associated with the lagged increase in population density.

\section{Data}

\subsection{Land use data}

Population data was obtained for the 33 current Administrative Districts (also called Boroughs, including the City of London and City of Westminster) of London going back to 1801 (Vision of Britain, 2006). Prior to 1965 and the creation of Greater London, there was a different legal and geographic definition for London and its boroughs. Censuses that had been conducted before the current boundaries were established were recoded to their present districts as part of the Great Britain Historical GIS (Geographic information system) Project (which releases data to the public via the Vision of Britain website) to give totals for current districts. The dataset therefore comprises 21 points in time for 33 areas giving 693 population data points. Comprehensive employment data by workplace local authority are available for 1921, and decennially from 1951, however, are unavailable for most areas prior to that point, dates which are critical to this analysis. Separate estimates of employment have been conducted for the City of London (City of London Workforce Info Census 2001, 2006), which are used in a descriptive way in this text. Density of population (and employment) were computed by dividing by the current area. The population density data is summarized in Figure 2.

\subsection{Transport network data}

This article defines the surface rail system as all currently existing London area heavy rail stations and lines that are not part of the 2006 Underground system, and the Underground stations are those that are part of the current system. ${ }^{5}$ Transport network

5 Some services have historically been transferred from one system to another; it is their current ownership that is used to define which system they are in. 


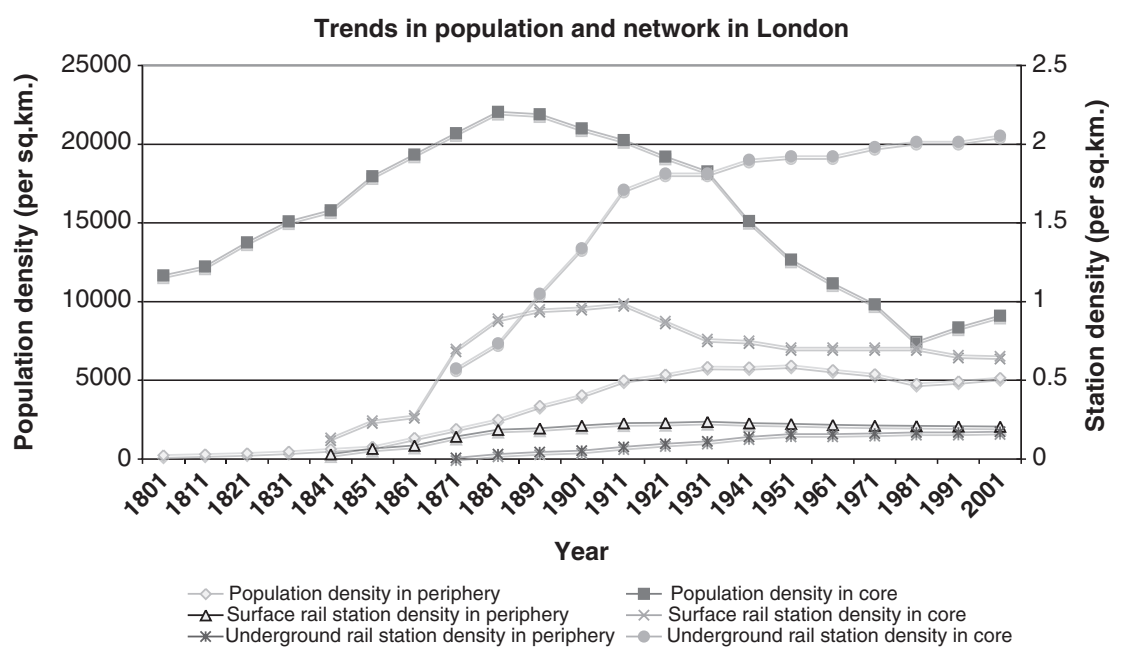

Figure 2. Trends in population and network in Greater London. Population density in the peripheral areas (suburbs) rises over time, as does network infrastructure. In the core, (including the City of London and nearby Boroughs) the Underground grows over time, while surface rail stations peaked about 1914, and the core begins depopulating between 1870 and 1880 .

data on the London Underground identifies each station on each line as a node, with $X$ and $Y$ coordinates, a date opened for a particular line. Some stations (about 25) were actually closed (as opposed to relocated), though these did not result in notable service reductions, most were low volume or were positioned too close to another station, several stations were on branches that were also served by surface rail lines. Underground stations that were opened and later closed are not considered as part of the analysis (i.e. it is as if they did not exist). Dates were obtained from Rose (1983) and Borley (1982). Small relocations of stations are ignored, as is the Circle Line, which shares platforms with the District, Metropolitan, or Hammersmith and City lines. Once a new line serves the station, that new line at the station is given a new node.

The number of Underground stations in each current Administrative District in each time period was determined. The density of Underground stations was computed by dividing the number of Underground nodes (each station per line is treated as a distinct node, so a station serving three lines is counted as three nodes) at a given time by the current area.

A similar procedure was undertaken for surface rail stations. However, passenger stations that were closed (not merely relocated) are considered in the analysis, so an area can have a negative net addition of surface rail stations.

Stations are used as a variable here. It should be noted that the number of stations and the length of network are very highly correlated in London. Length of the network is somewhat more ambiguous than stations to define, so stations are used. The network density data is summarized in Figure 2.

There are other attributes that describe transportation networks beyond the number of station, including service frequency, travel time, access time and cost, 
and fares for which a consistent and comprehensive time series of historical data is difficult to acquire. These data might improve the explanatory power of the model. Typically in transportation analysis, the impact area of a rail station is taken to be a 10 or $15 \mathrm{~min}$ walk to the station. With more discrete land use data, a finer resolution of network data, and tighter service areas, one could conduct a more detailed analysis.

\section{Methodology}

\subsection{Model specification}

Three models are specified, to predict population density, surface rail station density and Underground station density, respectively. The models predict the population (network) density $\left(D_{i, t}\right)$ of an area $i$ at time $t$. Because density changes slowly in physical infrastructure and housing, we expect that the density at time $t$ can be largely explained by the density in the previous time period, $\left(D_{i, t-1}\right)$. Including this lagged dependent variable on the right-hand side of the equation is a technique often used to reduce autocorrelation in the model, so in addition to having substantive theoretical reasons for inclusion, it has nice statistical properties.

Just as there is the potential for temporal autocorrelation in the time-series crosssection data, the data also has a very definite spatial structure, in this case, each area is adjacent to other areas, and connected to other areas via the transportation network in a non-uniform way. Incorporating a lagged variable that describes the state of the dependent variable in other areas in previous time periods will help capture the neighbor effects, where density in one area depends on the previous density in neighboring area(s). A weight matrix $W$ defines the relationships between areas, and is discussed in more detail subsequently.

Third, there are a set of explanatory variables $\left(X_{i, t-1}\right)$ that change over time and space. The level of infrastructure in an area, for instance, is hypothesized to affect future population density. In particular, construction that took place in the previous decade is expected to affect subsequent population density. (Similarly, population density is expected to positively affect future network infrastructure investment). The explanatory variables (or some subset of them) for neighbors may also be important explanatory factors.

Fourth, these explanatory variables also change in neighboring cells, so the matrix of explanatory variables is multiplied by the same weight matrix used above $\left(W X_{t-1}\right)$.

Fifth, there are a set of explanatory variables $\left(Z_{i}\right)$ that are specific to each area, but are constants. For instance, whether a district is north or south of the River Thames has often been posited as an explanatory factor in the construction of surface versus Underground rail networks in suburban London, and the economic nature of the areas differs. Testing this is important, but obviously, the location of a district vis-a-vis the Thames does not change over time.

Finally, there are a set of variables $\left(T_{t-1}\right)$ that describe overall conditions in the region, but do not vary by location. An example of this is the overall population density of London. Clearly if London were growing, areas within London are more likely to grow than if London were shrinking. 
The general model can be represented as follows:

$$
D_{i, t}=D_{i, t-1} \phi+W D_{t-1} \rho+X_{i, t-1} \beta+W X_{t-1} \chi+Z_{i} \zeta+T_{t-1} \psi
$$

where

$D_{i, t}$ is the density (population, Underground station, surface rail station) of area $i$ at time $t$,

$W$ is a matrix of spatial interaction weights,

$X_{i, t-1}$ is a vector of variables that change with both time and area,

$Z_{i}$ is a vector of area-specific variables that do not change with time,

$T_{t-1}$ is a vector of time-specific variables that do not change with area $\phi, \rho, \beta, \psi, \chi$ and $\zeta$ are parameters to be estimated.

It should be noted that full fixed effects, setting dummy variables for each area, are excluded from the specification. The reason for this is that the variability by area is one of the outcomes desired from the model, and this would foreclose on being able to draw conclusions from the results in that respect. Second, it prohibits testing of variables that remain constant over time $\left(Z_{i}\right)$. However, those variables capture some of the fixed effects. Similarly, no dummy variables for each year are used, as they provide no explanatory power. Instead, regional variables (e.g. regional population) which can be interpreted are used.

\subsection{Stratification: core versus periphery}

Transport infrastructure has different effects on areas destined to be employmentoriented (e.g. downtown) than those that are residential (e.g. suburbs). As discussed above, population data is available but employment by place of work is not available historically before 1921 except for some estimates for the City of London. For that reason, separate models are estimated for the core and periphery. The core is defined as having a high degree of employment, areas where the current ratio of persons working in the area to working-age residents exceeds one, (values in parentheses) (City of London (55.74), Westminster (3.65), Camden (1.84), Islington (1.38), Tower Hamlets (1.16), Kensington and Chelsea (1.08) and Southwark (1.02)) (National statistics: First Release: Labour Market Statistics, February 2006, 2006). These areas are seven of the eight boroughs of London that have a job to working-age population ratio greater than one. [The other area is Hillingdon (1.16), at the edge, the borough in which Heathrow Airport is located, and so is otherwise dissimilar from the core and is considered part of the periphery here]. The periphery constitutes the remainder of London. While these ratios have not remained constant over time, they do provide an indicator that distinguishes between two dissimilar areas. Certainly areas that were once peripheral have become part of the core, but changing the definition of the core over time would decrease the clarity of statistical interpretation.

Another way of stratifying would look at depopulation rather than current job to working-age population ratios. Separation of the City of London is the most obvious, as the area saw a depopulation from 1851 onwards and has the highest employment density. Other areas also saw significant early depopulation: Camden peaked in 1891, Hackney in 1921, Hammersmith and Fulham in 1931, Islington in 1911, Kensington and Chelsea in 1881, Southwark in 1901, Tower Hamlets in 1901 and Westminster in 1881. Empirical testing suggests that this set does not have the same explanatory power as the set described in the previous paragraph. 


\subsection{Time period}

The data is constructed as panel, with observations for 33 places every decade between 1801 and 2001. The time period analyzed for the dependent variable is between 1871 and 2001, inclusive. Though population data goes back to 1801 in the census, rail was not deployed until the late 1830 s and the Underground until the 1860 s. So the smallest set with data in all of the relevant variables, from 1871 on, is used. This also allows 10 and 20 year lags to be tested. The year 2001 is the last year for which UK Census data is available.

\subsection{Lag structure}

In the general model above, a one-period lag was identified. The use of a lag helps test cause and effect in a way that simultaneous variables could not. The data permit including longer lag periods for the explanatory variables, and this was tested. In general, the additional lags did not add explanatory power to the model and so are not reported, except in one case, where the lagged dependent variable (log of population density) is lagged for two periods in Model 1. This second-order lag helps give shape to the rate of growth (or decline) of population density.

\subsection{Log transformation}

The model presents the variables linearly. Log transforms of the variables were tested, and significantly helped explain population density, but did not help in predicting network density. In particular, while every area has population, some areas had no network in certain years, so additional assumptions about log transformation would be required if it were to be used. The use of linear models helps in the interpretation of relationships, though is admittedly, as all statistical models, a simplification and results in nonconstant elasticities.

\subsection{Neighbor definitions}

A weight matrix $W$ is used to define the relationships between areas. The asymmetric matrix takes on the value of 1 if the areas are neighbors as defined below and 0 otherwise. The model considers the 'neighbor nearest London', that is, neighbors that are between the area in question and the City of London. As neighbors, they are adjacent to the area. The intent is to account for the likely directionality in change in the dependent variable over time. An area that is immediately adjacent to one that has recently expanded (or contracted) may be more likely to feel the effects of those changes than one far away. As an area gets saturated, people are more likely to move to a proximate area than one farther away, and given that growth occurs outward from the center of London, they are likely to be most affected by their neighbor on the shortest path to the City of London. These are identified in Table 2.

This variable is lagged, rather than being treated co-temporaneously in order to be able to make some causal inferences with the result, which requires the cause to come before the effect. This neighbor definition can be thought of as reflecting a diffusion process, with the population (or network) diffusing over space. Ravenstein cited this process as the first of seven 'laws of migration', saying 'Most migrants only proceed a short distance, and toward centers of absorption.' (Ravenstein, 1885). 
Table 2. Borough and its neighbor on the shortest path to London

\begin{tabular}{|c|c|c|c|}
\hline Borough & $\begin{array}{l}\text { Neighbor nearest } \\
\text { London }\end{array}$ & Borough & $\begin{array}{l}\text { Neighbor nearest } \\
\text { London }\end{array}$ \\
\hline Barking and Dagenham & Newham & Hounslow & $\begin{array}{l}\text { Hammersmith } \\
\text { and Fulham }\end{array}$ \\
\hline Barnet & Camden & Islington & City of London \\
\hline Bexley & Greenwich & $\begin{array}{l}\text { Kensington } \\
\text { and Chelsea }\end{array}$ & Westminster \\
\hline Brent & Westminster & $\begin{array}{l}\text { Kingston upon } \\
\text { Thames }\end{array}$ & Merton \\
\hline Bromley & Lewisham & Lambeth & City of London \\
\hline Camden & City of London & Lewisham & Southwark \\
\hline City of London & City of London & Merton & Wandsworth \\
\hline Croydon & Lambeth & Newham & Tower Hamlets \\
\hline Ealing & Hammersmith and Fulham & Redbridge & Newham \\
\hline Enfield & Haringey & $\begin{array}{l}\text { Richmond upon } \\
\text { Thames }\end{array}$ & Wandsworth \\
\hline Greenwich & Tower Hamlets & Southwark & City of London \\
\hline Hackney & City of London & Sutton & Merton \\
\hline Hammersmith and Fulham & Kensington and Chelsea & Tower Hamlets & City of London \\
\hline Haringey & Islington & Waltham Forest & Hackney \\
\hline Harrow & Brent & Wandsworth & Westminster \\
\hline Havering & Barking and Dagenham & Westminster & City of London \\
\hline Hillingdon & Ealing & & \\
\hline
\end{tabular}

An alternate weight matrix that considered all adjacent areas weighted equally, was tested as well. This formulation did not produce results that were as significant, in addition to not having as sound a substantive reason for consideration in this kind of time-series analysis as the directionally defined weight matrix described in the previous paragraph, and for those reasons was not pursued further.

\subsection{Statistical techniques}

A number of statistical techniques have been proposed to deal with cross-sectional timeseries (panel) data. Two of the most widely used are the Arellano-Bond estimator (Arellano and Bond, 1991) and panel-corrected standard errors. The Arellano-Bond estimator employs generalized methods of moments, but has the feature of prohibiting the use of variables that do not change over time, which we have substantive reasons for including. In contrast, Beck and Katz (1996) in a widely cited paper suggest that the use of ordinary least squares (OLS) with panel corrected standard errors, using a lagged dependent variable not only has 'superior statistical properties', but also forces researchers to think carefully about the structure of their problem, rather than treating the relationships between observations as a 'nuisance' to be avoided. This finding was supported by Keele and Kelly (2006) who say 'if the process was dynamic, OLS with a [lagged dependent variable] provided estimates that were superior to the other models or estimators even in the presence of minor residual autocorrelation.'

The method used here, employing temporally lagged and spatially offset explanatory variables, has been called spatial-OLS (S-OLS) by Franzese Jr and Hays (2006), 
Table 3. Predicting $\log ($ population density)

\begin{tabular}{|c|c|c|c|c|c|c|}
\hline \multirow{2}{*}{$\begin{array}{l}\text { Model } 1 \\
\text { Predicting } \log \text { (population density) }\end{array}$} & \multicolumn{3}{|l|}{ Periphery } & \multicolumn{3}{|l|}{ Core } \\
\hline & Coefficient & SE & $P<|z|$ & Coefficient & $\mathrm{SE}$ & $P<|z|$ \\
\hline Log(population density) (L10) & $1.33 \mathrm{E}+00$ & $7.11 \mathrm{E}-02$ & 0.000 & $1.26 \mathrm{E}+00$ & $1.05 \mathrm{E}-01$ & 0.000 \\
\hline Log(population density) (L20) & $-3.76 \mathrm{E}-01$ & $6.32 \mathrm{E}-02$ & 0.000 & $-3.80 \mathrm{E}-01$ & $1.02 \mathrm{E}-01$ & 0.000 \\
\hline$\Delta$ Regional population & $1.15 \mathrm{E}-07$ & $2.45 \mathrm{E}-08$ & 0.000 & $2.25 \mathrm{E}-07$ & $3.53 \mathrm{E}-08$ & 0.000 \\
\hline$\Delta$ Surface rail density (L10) & $3.23 \mathrm{E}-01$ & $1.26 \mathrm{E}-01$ & 0.010 & $-6.71 \mathrm{E}-02$ & $1.25 \mathrm{E}-01$ & 0.590 \\
\hline$\Delta$ Underground density (L10) & $3.33 \mathrm{E}-01$ & $1.38 \mathrm{E}-01$ & 0.016 & $-7.23 \mathrm{E}-02$ & $6.78 \mathrm{E}-02$ & 0.287 \\
\hline$\Delta$ Neighbor surface rail density (L10) & $6.60 \mathrm{E}-02$ & $3.76 \mathrm{E}-02$ & 0.080 & $1.03 \mathrm{E}-01$ & $4.76 \mathrm{E}-02$ & 0.031 \\
\hline$\Delta$ Neighbor underground density (L10) & $-6.98 \mathrm{E}-02$ & $2.90 \mathrm{E}-02$ & 0.016 & $-3.33 \mathrm{E}-02$ & $2.67 \mathrm{E}-02$ & 0.213 \\
\hline Neighbor $\log$ (population density) (L10) & $1.78 \mathrm{E}-02$ & $8.38 \mathrm{E}-03$ & 0.034 & $-4.80 \mathrm{E}-02$ & $1.89 \mathrm{E}-02$ & 0.011 \\
\hline Distance to city of London & $7.14 \mathrm{E}-04$ & $2.04 \mathrm{E}-03$ & 0.727 & $1.34 \mathrm{E}-02$ & $5.84 \mathrm{E}-03$ & 0.021 \\
\hline North of River Thames & $1.12 \mathrm{E}-02$ & $9.94 \mathrm{E}-03$ & 0.260 & & & \\
\hline Constant & $1.95 \mathrm{E}-01$ & $1.59 \mathrm{E}-01$ & 0.220 & $1.41 \mathrm{E}+00$ & $2.68 \mathrm{E}-01$ & 0.000 \\
\hline Number of observations & 364 & & & 98 & & \\
\hline Number of groups & 26 & & & 7 & & \\
\hline Observations per group & 14 & & & 14 & & \\
\hline$R^{2}$ & 0.9931 & & & 0.9716 & & \\
\hline Wald $\chi^{2}$ & 9413.71 & & & 1996.99 & & \\
\hline$P<\chi^{2}$ & 0 & & & 0 & & \\
\hline
\end{tabular}

Note: SE calculated as panel-corrected SE (robust); L10 indicates 10-year lag, L20 indicates 20-year lag.

who after testing a variety of methods, say 'Nor do we necessarily see reason to push either of consistent estimators, S-ML [Spatial Maximum Likelihood] or S-2SLS-IV [Spatial Two-stage Least Squares with Instrumental Variables], in all cases because SOLS performs quite acceptably well under many circumstances and, indeed, in some cases, even better than these more complicated alternatives.'

The models are estimated using the panel corrected standard errors procedure (xtpcse) in the Stata software program (StataCorp., 2005), which employs a PraisWinsten regression with correlated panels corrected standard errors. This corrects for both simultaneous correlation within panels and serial autocorrelation between panels.

\section{Results}

Results from the regression models are presented in this section, following the procedures developed earlier in the article. In all, six models are presented: population density (Table 3), surface rail station density (Table 4) and Underground station density (Table 5) each for the periphery and the core of London, (numerous variants of these were tested, but are not included for space reasons). The paragraphs are identified by the hypotheses they test.

\subsection{Predicting population density}

The results for population density are shown in Table 3 for the periphery (suburban regions) and core, respectively. The $\log$ transformation of population density provides a slightly better fit than untransformed population density, so all of the 
Table 4. Predicting surface rail station density

\begin{tabular}{|c|c|c|c|c|c|c|}
\hline \multirow{2}{*}{$\begin{array}{l}\text { Model } 2 \\
\text { Predicting surface rail station density }\end{array}$} & \multicolumn{3}{|l|}{ Periphery } & \multicolumn{3}{|l|}{ Core } \\
\hline & Coefficient & SE & $P<|z|$ & Coefficient & SE & $P<|z|$ \\
\hline Surface rail density (L10) & $9.38 \mathrm{E}-01$ & $3.91 \mathrm{E}-02$ & 0.000 & $9.38 \mathrm{E}-01$ & $3.08 \mathrm{E}-02$ & 0.000 \\
\hline$\Delta$ Underground density (L10) & $-7.15 \mathrm{E}-02$ & $6.64 \mathrm{E}-02$ & 0.281 & $-3.95 \mathrm{E}-02$ & $7.38 \mathrm{E}-02$ & 0.593 \\
\hline$\Delta$ Population density (L10) & $1.26 \mathrm{E}-05$ & $4.19 \mathrm{E}-06$ & 0.003 & $-2.91 \mathrm{E}-05$ & $7.71 \mathrm{E}-06$ & 0.000 \\
\hline$\Delta$ Regional surface rail stations & $4.27 \mathrm{E}-04$ & $6.76 \mathrm{E}-05$ & 0.000 & $5.90 \mathrm{E}-03$ & $5.83 \mathrm{E}-04$ & 0.000 \\
\hline$\Delta$ Neighbor surface rail density (L10) & $2.96 \mathrm{E}-02$ & $2.18 \mathrm{E}-02$ & 0.176 & $1.36 \mathrm{E}-01$ & $5.13 \mathrm{E}-02$ & 0.008 \\
\hline$\Delta$ Neighbor underground density (L10) & $-9.13 \mathrm{E}-03$ & $1.59 \mathrm{E}-02$ & 0.567 & $-4.39 \mathrm{E}-02$ & $3.01 \mathrm{E}-02$ & 0.144 \\
\hline$\Delta$ Neighbor population density (L10) & $-7.30 \mathrm{E}-07$ & $1.49 \mathrm{E}-06$ & 0.624 & $2.31 \mathrm{E}-05$ & $5.97 \mathrm{E}-06$ & 0.000 \\
\hline Distance to city of London & $-1.07 \mathrm{E}-03$ & $5.57 \mathrm{E}-04$ & 0.055 & $-1.24 \mathrm{E}-02$ & $7.51 \mathrm{E}-03$ & 0.100 \\
\hline North of River Thames & $-4.33 \mathrm{E}-03$ & $6.23 \mathrm{E}-03$ & 0.486 & & & \\
\hline Constant & $3.29 \mathrm{E}-02$ & $1.69 \mathrm{E}-02$ & 0.052 & $9.47 \mathrm{E}-02$ & $4.75 \mathrm{E}-02$ & 0.046 \\
\hline Number of observations & 364 & & & 98 & & \\
\hline Number of groups & 26 & & & 7 & & \\
\hline Observations per group & 14 & & & 14 & & \\
\hline$R^{2}$ & 0.9474 & & & 0.9746 & & \\
\hline Wald $\chi^{2}$ & 2552.78 & & & 1459.12 & & \\
\hline$P<\chi^{2}$ & 0 & & & 0 & & \\
\hline
\end{tabular}

Note: SE calculated as panel-corrected SE (robust); L10 indicates 10-year lag.

Table 5. Predicting underground station density

\begin{tabular}{|c|c|c|c|c|c|c|}
\hline \multirow{2}{*}{$\begin{array}{l}\text { Model } 3 \\
\text { Predicting underground station density }\end{array}$} & \multicolumn{3}{|l|}{ Periphery } & \multicolumn{3}{|l|}{ Core } \\
\hline & Coefficient & SE & $P<|z|$ & Coefficient & $\mathrm{SE}$ & $P<|z|$ \\
\hline Underground density (L10) & $1.02 \mathrm{E}+00$ & $3.27 \mathrm{E}-02$ & 0.000 & $9.87 \mathrm{E}-01$ & $3.26 \mathrm{E}-02$ & 0.000 \\
\hline$\Delta$ Surface rail density (L10) & $-7.44 \mathrm{E}-02$ & $7.03 \mathrm{E}-02$ & 0.289 & $4.95 \mathrm{E}-01$ & $2.62 \mathrm{E}-01$ & 0.059 \\
\hline$\Delta$ Population density (L10) & $9.79 \mathrm{E}-06$ & $3.28 \mathrm{E}-06$ & 0.003 & $-4.32 \mathrm{E}-05$ & $1.39 \mathrm{E}-05$ & 0.002 \\
\hline$\Delta$ Regional underground stations & $2.89 \mathrm{E}-04$ & $8.86 \mathrm{E}-05$ & 0.001 & $1.74 \mathrm{E}-03$ & $3.12 \mathrm{E}-03$ & 0.576 \\
\hline$\Delta$ Neighbor surface rail density (L10) & $-1.97 \mathrm{E}-02$ & $1.70 \mathrm{E}-02$ & 0.246 & $-5.38 \mathrm{E}-02$ & $1.55 \mathrm{E}-01$ & 0.729 \\
\hline$\Delta$ Neighbor underground density (L10) & $2.04 \mathrm{E}-02$ & $1.15 \mathrm{E}-02$ & 0.077 & $2.12 \mathrm{E}-02$ & $1.11 \mathrm{E}-01$ & 0.849 \\
\hline$\Delta$ Neighbor population density (L10) & $1.45 \mathrm{E}-06$ & $1.47 \mathrm{E}-06$ & 0.325 & $-3.30 \mathrm{E}-06$ & $1.54 \mathrm{E}-05$ & 0.830 \\
\hline Distance to city of London & $-5.63 \mathrm{E}-04$ & $3.06 \mathrm{E}-04$ & 0.066 & $-1.20 \mathrm{E}-02$ & $1.06 \mathrm{E}-02$ & 0.261 \\
\hline North of River Thames & $9.70 \mathrm{E}-03$ & $4.98 \mathrm{E}-03$ & 0.051 & & & \\
\hline Constant & $4.48 \mathrm{E}-03$ & $8.05 \mathrm{E}-03$ & 0.578 & $1.12 \mathrm{E}-01$ & $1.09 \mathrm{E}-01$ & 0.305 \\
\hline Number of observations & 364 & & & 98 & & \\
\hline Number of groups & 26 & & & 7 & & \\
\hline Observations per group & 14 & & & 14 & & \\
\hline$R^{2}$ & 0.9649 & & & 0.9767 & & \\
\hline Wald $\chi^{2}$ & 4430.88 & & & 1387.55 & & \\
\hline$P<\chi^{2}$ & 0 & & & 0 & & \\
\hline
\end{tabular}


Table 6. Elasticities

\begin{tabular}{lll}
\hline Elasticities & Periphery & Core \\
\hline Rail (combined) on population density & 0.0023 & -0.0038 \\
Change in population density on surface rail density & 0.0023 & -0.0065 \\
Change in population density on underground rail density & 0.0027 & -0.0041
\end{tabular}

population-density variables are transformed. Overall population density at time $t$ is highly and positively correlated with one-period lagged population-density and negatively and significantly correlated with two-period lagged population density.

Hypothesis(i): (a) Population density in the periphery is positively associated with the lagged increase in density of new surface $(P=0.010)$ and Underground rail stations $(P=0.016)$. Evaluating this more formally as an elasticity indicates that a one percent increase in capacity (evaluated at a typical value of 0.3 stations (both surface and Underground) per $\mathrm{km}^{2}$ is associated with a later increase in population density of $0.22 \%$. Key elasticities for the six models are summarized in Table 6.

Hypothesis(i): (b) There are lagged spatial effects, population density in the periphery is positively associated $(P=0.034)$ with the population density of the nearest borough between it and London (neighbor effect).

Hypothesis(i): (c) Neighbor effects on population density for network infrastructure were positive for surface rail $(P=0.080)$, and negative for Underground stations $(P=0.016)$. Notably this trend holds for both the core and periphery, though in the core, Underground density is insignificant.

Hypothesis(i): (d) The relationship between population density in the core and the lagged increase in density of new surface and Underground rail stations is negative, but not statistically significant.

After controlling for other variables, we cannot corroborate that areas north of the River Thames will develop at a higher density than areas south of the River, as the variable is statistically insignificant (and negative), which again may be due to the lagged-population density as an explanatory variable.

Some other observations are worth noting. In contrast to the periphery, in the core, the farther one is from the city, the higher the population density, as the close-in areas have more commercial activity pricing out the residential. As might be expected, the greater the overall population of London, the higher the population density.

\subsection{Predicting rail station density}

Turning to the question of rail station density, results are in Tables 4 and 5 for surface and Underground respectively, with separate models for the periphery and core. Overall, rail station density is strongly determined by previous density, as the built environment is slow to change.

Hypothesis(ii): (a) In the periphery, change in population density is a positive and significant factor in explaining rail station density $(P=0.003)$. Each $1 \%$ increase in population density (10 years past) leads to a $0.23 \%$ increase in surface rail station density and a $0.27 \%$ increase in Underground station density. 
Hypothesis(ii): (b) Neighboring population is insignificant in explaining surface rail and Underground station density in the periphery.

Hypothesis(ii): (c) Similarly, neighboring infrastructure is generally insignificant in explaining surface rail and Underground station density in the periphery. Neighboring Underground stations are weakly positive on Underground station density $(P=0.077)$.

Hypothesis(ii): (d) Surface rail and Underground stations are statistically insignificant substitutes, it cannot be corroborated that an increase in new Underground likely leads to a decrease in surface rail stations, or vice versa.

Hypothesis(ii): (e) Next looking at the core, change in population density from 10 to 20 years ago is negative $(P=0.000$ surface, $P=0.002$ Underground), the greater the increase in population, the fewer stations built (elasticity $-0.65 \%$ for surface rail, $-0.41 \%$ for Underground rail). This may seem counter-intuitive, but recall that residential and commercial uses are competing for the same space, so if employment density is increasing, it is pricing residential uses out.

In contrast with the periphery model, in the core lagged-neighboring surface rail effects are significant in predicting surface rail $(P=0.008)$. There is a positive association between change in population density in neighboring areas and surface rail stations $(P=0.000)$.

In the core, new surface rail stations positively affect Underground construction $(P=0.059)$, indicating complementarity rather than substitution effects. This is consistent with the first Underground lines (the Metropolitan and District lines in particular) which connected mainline rail stations. The converse does not hold, new Underground stations do not encourage new surface stations $(P=0.593)$.

Turning back to the periphery, the River Thames is statistically insignificant for surface rail, though negative as observed in other sources. It is marginally positive $(P=0.051)$ for the Underground, indicating that there is a skew of more Underground services north of the River Thames after accounting for a number of other factors.

Some regional factors matter, the greater the increase in regional rail stations, the greater the increase in local density (as would be expected). Distance to London is a negative factor, the greater the distance to London, the lower the station density. Other factors were statistically insignificant.

\section{Discussion and conclusions}

This research examined the spatial co-development of rail networks and population in London between 1871 and the present. It found that in the periphery of London, rail is a precursor to population growth and that population growth is a precursor to rail deployment. Train service led to a suburbanization of countryside and increased population of new developments, which attracted more railways. This is a positive feedback system, but not one that is unchecked, as there are many other factors that limit the growth of either network or place.

However, the city center is different, the same rail lines that enabled people to move to the suburbs helped them move from the city. Overall, rail transformed the London city center to a place with high-residential and commercial densities to one with lowresidential and very high-commercial densities.

The research also examined the differences between different rail technologies: Underground and surface in shaping cities. Importantly, the Underground was able to 
get into the very heart of London in a way that surface rail was not. Though the depopulation of the City of London began with surface rail, it accelerated with the introduction of the Underground. Qualitatively, the Underground serves both commuting to work and business-to-business transactions, while surface rail, because of its costs and location, serves primarily commuting traffic.

Over time the Underground became more train-like, with the suburban extensions acting like commuter rail lines, and in some cases, taking over existing surface rail lines.

Generalizing the observations from London, we observe there are existing markets served by older modes of transportation. A new mode is developed which is superior in some ways to existing modes. It is built in certain markets (the best markets) and displaces market share from those existing modes. It also develops new travel demands (induced demand) because of the lower cost/higher quality at same cost it provides. Eventually, as it exhausts existing markets, it seeks to develop new markets. At this time it moves from following existing development to leading new land use. This point of exhaustion may occur when profitability decreases from super-normal profits to normal or below-normal profits, but that is beyond the scope of this article to test.

The development of new markets is speculative, with a much higher risk associated with it than serving existing markets. An advantage is the lower cost of deployment found for two reasons: many of the fixed costs of the system have already been paid for (trains, depots, etc.), and land is cheaper in areas that are undeveloped. A second advantage is the ability to capture more of the revenue if the railway acts as developer, or receives subsidies from developers.

The two systems, land development and networks, have co-developed over the course of decades and centuries. Returning to the theme from the introduction, this article finds strong historical evidence for what the transportation literature terms induced demand', corroborating earlier research, and shows that this demand is not simply additional traffic from existing residents, but also in the creation of new residences. This has a number of implications for practice. Proposals to 'build our way out of congestion' must acknowledge that capacity increases will generate subsequent travel demand increases from land use changes even 10-20 years downstream, in addition to short-term changes due to behavioral shifts from people who are not relocating. This does not mean that adding capacity is necessarily wrong or futile, just that failure to account for these systematic responses will result in unwelcome surprises. It also shows evidence of 'induced supply', the agents responsible for building infrastructure follow demand to some extent. Interestingly, the strengths of the two effects, induced supply and induced demand, are about equal. Just as infrastructure utilization cannot be assessed independent of the land use consequences, land use decisions cannot be accurately made divorced from infrastructure considerations. Decision-makers will respond to pressures (either potential profit if private sector, or potential votes in a democracy) placed on the infrastructure system by existing demand and expand or extend it in response.

\section{Acknowledgements}

This research has been supported by the UK Economic and Social Research Council while visiting the Centre for Transport Studies at Imperial College. This material is based upon work supported by the US National Science Foundation under Grant No. 0236396. Any opinions, findings and conclusions or recommendations expressed in this material are those of the author 
and do not necessarily reflect the views of the National Science Foundation. Robert Noland is thanked for his detailed comments on an earlier draft.

\section{References}

Arellano, M. and Bond, S. (1991) Some tests of specification for panel data. Review of Economic Studies, 58: 277-297.

Beck, N. and Katz, J. (1996) Nuisance vs. substance: specifying and estimating time-series-crosssection models. Political Analysis, 6: 1-36.

Behrens, R. and Kane, L. (2004) Road capacity change and its impact on traffic in congested networks: evidence and implications. Development Southern Africa, 21: 587-602.

Bellomo, S., Robert, B., Voorhees, A. (1970) Factors, trends, and guidelines related to trip length. Technical report. : Highway Research Board, National Research Council.

Boarnet, M. (1998) Spillovers and the locational effects of public infrastructure. Journal of Regional Science, 38: 381-400.

Borley, H. (1982) Chronology of London railways. Oakham, Leicester, England: Railway and Canal Historical Society.

Bressey, C. and Lutyens, E. (1938) Highway development survey 1937. London: Technical report, Ministry of transport, HMSO.

Cervero, R. and Hansen, M. (2002) Induced travel demand and induced road investment: a simultaneous equation analysis. Journal of Transport Economics and Policy, 36: 469-490.

Cervero, R. and Kockelman, K. (1997) Travel demand and the 3 Ds: density, diversity, and design. Transportation Research D, 2: 199-219.

Cervero, R. (2002) Induced travel demand: research design, empirical evidence, and normative policies. Journal of Planning Literature, 17: 3-20.

Cervero, R. (2003) Road expansion, urban growth, and induced travel: a path analysis. Journal of the American Planning Association, 69: 145-164.

Chi, G., Voss, P., Deller, S. (2006) Rethinking highway effects on population change. Public Works Management \& Policy, 11: 18.

City of London Workforce Info Census 2001 (2006) Technical report, London Department of Planning and Transportation, London.

Clark, C. (1957) Transport: maker and breaker of cities. Town Planning Review, 28: 237-250.

Croome, D. and Jackson, A. (1993) Rails Through the Clay. London: Capital Transport.

Deacon, T. (1997) The Symbolic Species: The Co-evolution of Language and the Brain. New York: WW Norton.

Downs, A. (2004) Still Stuck in Traffic: Coping With Peak-Hour Traffic Congestion. Washington, DC: Brookings Inst Press.

Durham, W. (1991) Coevolution: Genes, Culture, and Human Diversity. Palo Alto, CA: Stanford University Press.

Foxell, C. (2005) Rails to Metro-Land. Clive Foxell, Chesham, England: Bucks.

Frank, L. and Pivo, G. (1994) Impacts of mixed use and density on utilization of three modes of travel: single-occupant vehicle, transit, and walking. Transportation Research Record, 1466: $44-52$.

Franzese Jr., R.J. and Hays, J.C. (2007) Spatial econometric models of cross-sectional interdependence in political science panel and time-series-cross-section data. Political Analysis, DOI 10.1093/pan/mpm005.

Fulton, L., Noland, R., Meszler, D., Thomas, J. (2000) A statistical analysis of induced travel effects in the US Mid-Atlantic Region. Journal of Transportation and Statistics, 3: 1-14.

Garrison, W. and Levinson, D. (2006) The Transportation Experience: Policy, Planning, and Deployment. New York, US: Oxford University Press.

Gibbons, S. and Machin, S. (2004) Valuing Rail Access Using Transport Innovations. Centre for Economic Performance. London: London School of Economics and Political Science.

Gifford, J. (1983) An Analysis of the Federal Role in the Planning, Design, and Deployment of Rural Roads, Toll Roads, and Urban Freeways. PhD thesis, University of California at Berkeley, UCB-ITS-DS-83-2. 
Goodwin, P., Hass-Klau, C., Cairns, S. (1998) Evidence on the effects of road capacity reduction on traffic levels. Traffic Engineering + Control, 39: 348-354.

Goodwin, P. and Noland, R. (2003) Building new roads really does create extra traffic: a response to Prakash et al. Applied Economics, 35: 1451-1457.

Goodwin, P. (1975) Variations in travel between individuals living in areas of different population density. Conference Proceedings, PTRC Summer Annual Meeting. Coventry: University of Warwick.

Goodwin, P. (1996) Empirical evidence on induced traffic. Transportation, 23: 35-54.

Graham, D. (2005) Transport investment, agglomeration and urban productivity. World Bank Urban Research Symposium, 4-6.

Gramlich, E. (1994) Infrastructure investment: a review essay. Journal of Economic Literature, 32: $1176-1196$.

Hansen, M. and Huang, Y. (1997) Road supply and traffic in urban areas: a panel study. Transportation Research A, 31: 205-218.

Hobbs, D. and Campbell, R. (1967) Traffic flow and population change: Missouri towns and cities. Business and Government Review, 8: 5-11.

Humphrey, C.R. and Sell, R.R. (1975) The impact of controlled access highways on growth in pennsylvania nonmetropolitan communities, 1940-1970. Rural Sociology, 40: 332-43.

Keele, L. and Kelly, N. J. (2006) Dynamic models for dynamic theories: the ins and outs of lagged dependent variables. Political Analysis, 14: 186-205http://pan.oxfordjournals.org/cgi/content/ abstract/14/2/186.

Levinson, D. (2005) The evolution of transport networks. In D. Button and K. Hensher (eds) Handbook of Transport Strategy, Policy and Institutions Volume 6 (Handbooks in Transport), pp. 175-188 chapter 11. Oxford: Elsevier.

Levinson, D. and Chen, W. (2005) Paving new ground: a markov chain model of the change in transportation networks and land use. In D. Levinson and K. Krizek (eds) Oxford: Elsevier.

Levinson, D. and Kanchi, S. (2002) Road capacity and the allocation of Time. Journal of Transportation and Statistics, 5: 25-46.

Levinson, D. and Karamalaputi, R. (2003) Induced Supply: a model of highway network expansion at the microscopic level. Journal of Transport Economics and Policy, 37: 297-318.

Lichter, D. and Fuguitt, G. (1980) Demographic response to transportation innovation: the case of the interstate highway. Social Forces, 59: 492-512.

Lowry, G. (1979) Streetcar Man: Tom Lowry and the Twin City Rapid Transit Company. Biographies \& Memoirs: General. Minneapolis: Lerner Pub Group.

McDonald, J. and Osuji, C. (1995) The effect of anticipated transportation improvement on residential land values. Regional Science and Urban Economics, 25: 261-278.

McLean, E. and Adkins, W. (1971) Freeway effects on residential mobility in urban neighborhoods. Highway Research Record, 356: 95-104.

Miller, J. (1979) Interstate highways and job growth in nonmetropolitan areas: a reassessment. Transportation Journal, 19: 78-81.

Mogridge, M. (1997) Metropolis or region: on the development and structure of London. Regional Studies, 31: 97-115.

Mokhtarian, P., Samaniego, F., Shumway, R., Willits, N. (2002) Revisiting the notion of induced traffic through a matched-pairs study. Transportation, 29: 193-220.

National statistics: First Release: Labour Market Statistics, February 2006. Technical report, Centre for Economic and Social Inclusion. London, 15 February 2006. http://www.cesi.org.uk/ statsdocs/0602/lmslond0206.pdf Table 12 (Accessed 15 October 2007).

Newman, P. and Kenworthy, J. (1992) Is there a role for physical planners. Journal of the American Planning Association, 58: 353-362.

Noland, R. and Lem, L. (2002) A review of the evidence for induced travel and changes in transportation and environmental policy in the US and the UK. Transportation Research Part D: Transport and Environment, 7: 1-26.

Parthasarathi, P., Levinson, D., Karamalaputi, R. (2003) Induced demand: a microscopic perspective. Urban Studies, 40: 1335-1351.

Pushkarev, B. and Zupan, J. (1977) Public Transportation and Land Use Policy. Bloomington, IN: Indiana University Press. 
Rae, J. B. (1971) The Road and the Car in American Life. Nonfiction: Automotive: Traffic \& Safety, Cambridge, MA: The MIT Press.

Ravenstein, E. G. (1885) The laws of migration. Journal of the Statistical Society of London, 48: $167-235$.

Richardson, H. (1973) The Economics of Urban Size. Lanham, MD: Lexington Books.

Rose, D. (1983) The London Underground: A Diagrammatic History. Douglas Rose. London: Capital Transport Publishing, 7 Revised Edition.

SACTRA (1994) Trunk roads and the generation of traffic. Technical report, Standing Advisory Committee For Trunk Road Assessment (SACTRA). HMSO.

Simmons, J. (1978) The Railway in England and Wales, 1830-1914. Leicester: Leicester University Press.

StataCorp. (2005) Intercooled Stata 8.2 for Mac OS X. StataCorp., College Station, Texas.

Steiner, R. (1994) Residential density and travel patterns: review of the literature. Transportation Research Record, 1466: 37-43.

Terance, R. and Isserman, A. (1994) New highways as economic development tools: an evaluation using quasi-experimental matching methods. Regional Science and Urban Economics, 24: 723-751.

The Portobello and St. Quintin estates (1973) In Survey of London: volume 37: Northern Kensington, British History Online, 298-332. http: //www.british-history.ac.uk/report. asp?compid $=49881$. Accessed: 20 February 2007.

Vision of Britain, A. (2006) A vision of britain through time. Technical report. http:// www.visionofbritain.org.uk/index.jsp (Accessed 15 October 2007).

Voss, P. and Chi, G. (2006) Highways and population change. Rural Sociology, 71: 33-58.

Warner, S. B. J. (2004) Streetcar Suburbs : The Process of Growth in Boston, 1870-1900. 2nd edn (p. 208) Nonfiction: Social Sciences: Sociology: General, Harvard University Press.

Xie, F. and Levinson, D. (2008) The Weakest Link: a model of the decline of surface transportation networks. Transportation Research part E, 44: 100-113. 